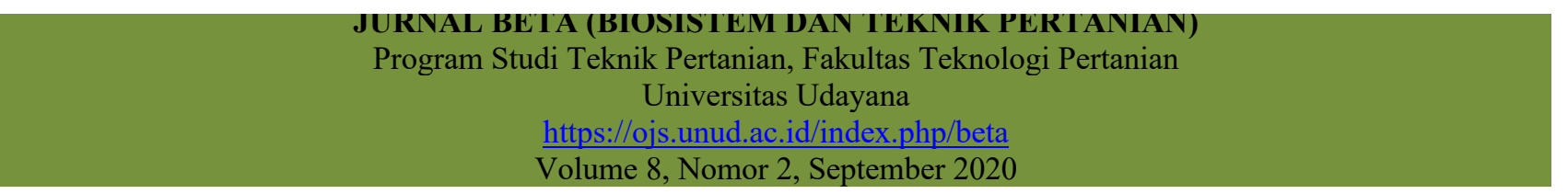

\title{
Pengaruh Konsentrasi Asap Cair Batang Bambu Tabah (Gigantochloa nigrociliata BUSE-KURZ) Terhadap Karakteristik Ikan Lele (Clarias Sp) Asap
}

\section{The Effect of Liquid Smoke Concentration of Tabah Bamboo (Gigantochloa nigrociliata BUSE-KURZ) on Smoke Catfish (Clarias Sp) Characteristics}

\author{
I Ketut Agus Sandi Andika, Pande Ketut Diah Kencana*, Ida Bagus Putu Gunadnya \\ Program Studi Teknik Pertanian, Fakultas Teknologi Pertanian, Universitas Udayana, Badung, Bali, Indonesia \\ *E-mail: diahkencana@unud.ac.id
}

\begin{abstract}
Abstrak
Ikan lele adalah makanan kesehatan yang mengandung nilai gizi yang baik. Oleh karena itu penting untuk menemukan metode untuk melestarikan ikan ini untuk meningkatkan konsumsi mereka. Asap cair batang bambu tabah dapat digunakan sebagai metode untuk membuat produk olahan lele. Tujuan penelitian ini untuk mengetahui pengaruh konsentrasi dan suhu pemasakan terhadap karakteristik ikan lele asap dalam larutan asap cair batang bambu. Dan juga untuk mengetahui konsentrasi dan suhu terbaik untuk kualitas organoleptik terbaik dari lele asap yang dilarutkan dalam larutan asap cair bambu tabah. Metode penelitian ini adalah menggunakan (RAL) Rancang Acak Lengkap Faktorial dengan dua faktor. Faktor yaitu konsentrasi asap cair, $1 \%, 2 \%, 3 \%$. dan suhu pemasakan, yaitu dari suhu $60^{\circ} \mathrm{C}, 80^{\circ} \mathrm{C}$, dan $100^{\circ} \mathrm{C}$. Kombinasi terbaik adalah konsentrasi bambu tabah $3 \%$ dan suhu pemanasan $100^{\circ} \mathrm{C}$, pemanasan dilakukan dengan waktu 4 jam dan menghasilkan Nilai pH 5,61, kadar Air 56,78\%, Kadar Abu 2,17\%, Kadar Protein 13,46\% , Kadar Lemak 5,55\%, Warna 4,67 (coklat keemasan), Aroma 4,80 (aroma cukup) Rasa 4,93 (testeful), Tekstur 4,53 (padat).
\end{abstract}

Kata kunci: asap cair, bambu tabah, ikan asap, ikan lele, karakteristik

\begin{abstract}
Catfish is a health food that contains good nutritional value. It is therefore important to find methods to conserve these fish to increase their consumption. Liquid smoke of stoic bamboo stems can be used as a method for making catfish processed products. The purpose of this study was to determine the effect of cooking concentration and temperature on the characteristics of smoked catfish in a bamboo stick liquid smoke solution. And also to find out the best concentration and temperature for the best organoleptic quality of smoked catfish dissolved in a stoic bamboo liquid smoke solution. The method of this research is to use a factorial completely randomized design with two factors. The first factor is the concentration of liquid smoke, namely from $1 \%, 2 \%$, and $3 \%$. The second is cooking temperature, which is from $60 \mathrm{oC}, 80 \mathrm{oC}$, and $100 \mathrm{oC}$. The best combination is bamboo concentration of $3 \%$ and a heating temperature of $100 \mathrm{oC}$, heating is done in 4 hours and produces a $\mathrm{pH}$ value of 5.61, a moisture content of $56.78 \%$, an ash content of $2.17 \%$, a protein content of $13.46 \%$, a fat content $5.55 \%$, Color 4.67 (golden brown), Aroma 4.80 (aroma enough) Taste 4.93 (testeful), Texture 4.53 (solid).
\end{abstract}

Keyword: liquid smoke, stoic bamboo, smoked fish, catfish, characteristics

\section{PENDAHULUAN}

Ikan lele (Clarias sp) adalah sumber makanan yang bernutrisi tinggi. Ikan lele biasanya di konsumsi dalam keadaan segar dengan proses pengolahan yang lumayan rumit. Hal ini mengakibatkan rendahnya tingkat konsumsi ikan lele, padahal nilai gizi ikan sangat baik. Melihat hal ini maka diperlukannya suatu metode perlakuan kusus pada pengolahan ikan lele gunu meningkatkan nilai konsumsi ikan lele. Pengasapan menjadi salah satu metode yang digunakan dalam mempertahankan daya awet ikan serta dapat memberikan aroma yang enak warna coklat atau kehitaman pada produk, nilai tekstur lebih baik cita rasa yang khas least (Wibowo, 1996).
Ikan menjadi salah satu sumber pangan dimana memiliki nilai mutu yang tinggi. Ikan memiliki kelemahan yaitu salah satu bahan pangan yang mudah rusak (highly perishable food). Salah satu usaha untuk meningkatkan pengawetan ikan adalah dengan menggunakan teknik pengasapan. Pengasapan merupakan kombinasi dari proses pengarangan, pemanasan yang bertujuan memberikan rasa (aroma) yang khas.

Pengasap adalah metode yang paling banyak dilakukan oleh masyarakat, pengasapan yang paling sering digunakan adalah pengasapan menggunakan suhu tinggi mencapai $100^{\circ} \mathrm{C}$ hingga $120^{\circ} \mathrm{C}$ dengan meletakan ikan diatas sumber panas, sehingga terjadi kontak langsung dengan asap. Salah satu cara yang 
dapat digunakan untuk mengawetkan ikan adalah dengan cara pengasapan. Selama ini, pengasapan yang dilakukan masih menggunakan metode tradisional. Pengasapan tradisional masih memiliki kelemahan seperi flavor dan konsentrasi konstituen asap tidak seragam, waktu pemanasan dan suhu tidak sama ini dapat menyebabkan produk yang dihasilkan tidak merata. Semakin berkembangnya pengetahuan, pengasapan ikan dapat dilakukan dengan penggunaan asap cair sebagai bahan pengawet ikan yang lebih aman dan dapat memperpanjang masa simpan ikan. Asap cair adalah pencampuran larutan dari dispersi asap kayu didalam air dibuat dengan mengkondensasi asap cair kayu. Asap dapat di aplikasikan secara komersal sebagai pemberi aroma pada ikan dan daging karena komponen flavor dari senyawa fenolik Dari kandungan yang terdapat pada asap cair batang bambu tabah serta ingin memaksimalkan dalam pemanfaatan asap cair batang bambu tabah, maka perlu adanya suatu kajian untuk pengaplikasian asap cair batang bambu tabah pada pengawetan ikan dan menambah citarasa yang khas pada ikan. Budijanto et al. (2019), mengemukakan bahwa penggunaan asap cair mempunyai banyak keuntungan diantaranya menjadi lebih mudah diaplikasikan, pengolahan lebih cepat, dapat memberikan karakteristik khas pada produk akhir diantaranya pada aroma, warna, dan rasa yang menarik, tidak mencemari lingkungan serta tidak menyebabkan adanya polusi udara.

Tujuan penelitian ini adalah Untuk mengetahui pengaruh suhu dan konsentrasi asap cair batang bambu tabah terhadap nilai Karakteristik ikan lele asap yang dilarutkan dalam larutan asap cair batang bambu tabah.

\section{METODE PENELITIAN}

\section{Tempat dan Waktu Penelitian}

Penelitian ini dilaksanakn di laboraturium Analisis Pangan, Laboratorium Ergonomi, Perbengkelan, dan Pascapanen, Universitas Udayana. Dilaksanakan pada bulan Mei sampai bulan Juli 2019.

\section{Alat dan Bahan Penelitian}

Alat penelitian yang digunakan yaitu kertas saring, baskom, panic, thermometer, cold box, spatula, oven listrik, timbangan analitik, Erlenmeyer, desikator, labu kjedal, soxhlet, cawan porselin, penjepit, mufflet purnace, gelar ukur, gelas beker, pisau, talenan, mortal, pastel, $\mathrm{pH}$ meter, dan lanu lemak.

Penelitian ini menggunakan bahan yaitu asap cair dari batang bambu tabah yang sudah jadi. Ikan lele segar dengan ukuran panjang 20-25 cm dengan berat sekitar 200g setiap ekornya sebanyak 40 ekor yang digunakan ikan lele yang diperoleh dari salah satu kolam budidaya Kelompok Ikan Mina Lestari Ubung Bali.

\section{Pelaksanaan Penelitian}

Pengaplikasian Asap Cair Batang Bambu Tabah

Bahan baku yang digunakan yaitu ikan lele segar dengan ukuran panjang ikan 20-25 cm dengan berat sekitar 200g per ekornya sebanyak 40 ekor yang digunakan yaittu ikan lele yang dari kolam budidaya kelompok ikan Mina Lestari Ubung Bali. Bahan baku yang di dapat di taruh kedalam cold box yang diisi es dan langsung dibawa ke Laboraturium penelitian. Ikan di bersihkan dengan membuang insang dan isi perut ikan. Lalu dikluarkan dan dicuci ikan untuk menghilangkan sisa kotoran dan lender, dan darah yang masih melekat pada ikan.

Ikan lele direndam dengan menggunakan larutan asap cair batang bambu tabah dengan konsentrasi 1\%, 2\% dan 3\% lama perendaman selama 60 menit, ikan lele harus terendam sampai keseluruhan permukaannya. Setelah proses perendaman, ditiriskan selama 15 menit. Tahapan selanjutnya Adalah proses pemasakan ikan dengan menggunakan oven listrik dengan suhu yang berbeda, yaitu $60^{\circ} \mathrm{C}, 80^{\circ} \mathrm{C}, 100^{\circ} \mathrm{C}$ dan lama pemasakan selama 4 jam. Ikan lele disusun rapi di dalam oven dengan tujuan pematangan yang merata pada keseluruhan permukaan ikan.

\section{Parameter yang diamati}

Parameter yang diamati dalam penelitian ini yaitu, kadar air, dengan metode, pemanasan (Sudarmaji et al, 1997), kadar abu dengan metode pengabuan (Sudarmaji et al, 1997), kadar protein dengan metode semi-Kjeldhal (Sudarmaji et al, 1997), kadar lemak dengan metode penguapan (Sudarmaji et al, 1997), nilai $\mathrm{pH}$ menggunakan $\mathrm{pH}-$-meter (AOAC, 1995), dan uji sensorik pada produk ikan lele asap mengacu pada uji sensorik ikan lele.

\section{HASIL DAN PEMBAHASAN}

\section{Nilai pH}

Nilai pH merupakan salah satu parameter yang penting pada suatu produk olahan, kususnya ikan olahan. Adapun nilai rata - rata $\mathrm{pH}$ ikan lele asap dari kombinasi perlakuan pada Tabel 1. Berdasarkan Hasil Analisis Sidik Ragam yang telah dilakukan menunjukkan bahwa perlakuan konsentrasi asap cair dan suhu pemasakan berpengaruh sangat nyata $(\mathrm{P}<0,01) \quad$ serta kombinasi kedua perlakuan berpengaruh nyata $(\mathrm{P}<0,05)$ terhadap nilai $\mathrm{pH}$ ikan lele asap yang dihasilkan. Tabel 1. Menunjukkan bahwa $\mathrm{pH}$ ikan lele asap yang dihasilkan berkisar antara 5,48 hingga 5,90. Nilai $\mathrm{pH}$ terendah adalah 5,48 terdapat pada perlakuan konsentrasi 3\% dan suhu pemasakan $100^{\circ} \mathrm{C}\left(\mathrm{K}_{3} \mathrm{~S}_{3}\right)$. Nilai $\mathrm{pH}$ tertinggi adalah 5,90 terdapat pada perlakuan konsentrasi $1 \%$ dan suhu pemasakan $60^{\circ} \mathrm{C}\left(\mathrm{K}_{1} \mathrm{~S}_{3}\right)$. Nilai rata-rata $\mathrm{pH}$ kombinasi perlakuan konsentrasi asap cair dan suhu pemasakan adalah 5,61. Penggunaan asap cair mempunyai pengaruh terhadap nilai pH ikan. Karena 
semakin tinggi konsentrasi asap cair yang ditambah pada produk maka akan semakin rendah nilai $\mathrm{pH}$-nya.

Tabel 1. Nilai rata-rata $\mathrm{pH}$ ikan lele asap dari kombinasi perlakuan konsentrasi dan suhu pemasakan

\begin{tabular}{ccccc} 
& $\mathrm{S} 1$ & $\mathrm{~S} 2$ & $\mathrm{~S} 3$ & $\begin{array}{c}\text { Rata- } \\
\text { rata }\end{array}$ \\
$\mathrm{K} 1$ & $5,50^{\mathrm{e}}$ & $5,70^{\mathrm{c}}$ & $5.90^{\mathrm{a}}$ & 5.70 \\
$\mathrm{~K} 2$ & $5,50^{\mathrm{e}}$ & $5,60^{\mathrm{d}}$ & $5,80^{\mathrm{b}}$ & 5.63 \\
$\mathrm{~K} 3$ & $5.30^{\mathrm{f}}$ & $5,45^{\mathrm{e}}$ & $5,70^{\mathrm{c}}$ & 5.48 \\
$\begin{array}{c}\text { Rata- } \\
\text { rata }\end{array}$ & 5.43 & 5.58 & 5.80 & 5,61 \\
\hline
\end{tabular}

Keterangan: Huruf yang sama dibelakang angka pada baris dan kolom yang sama menunjukkan nilai yang tidak berbeda nyata $(\mathrm{P}>0.05)$.

\section{Kadar Air}

Air yang terkandung dalam bahan makanan sangat berperan penting dalam menentukan daya trima (acceptability), nilai dan masa simpat produk pangan (Winarno. 1997). Kadar air merupakan karakteristik yang sangat penting pada bahan pangan, karena air dapat mempengaruhi kenampakan, tekstur, dan cita rasa pada bahan pangan. Kadar air yang tinggi mengakibatkan mudahnya bakteri, kapang, dan khamir untuk berkembang biak, sehingga akan terjadi perubahan pada bahan pangan (Afrianto dan Liviawaty, 1989). Adapun rata-rata nilai kadar air ikan Lele Asapdari berbagai kombinasi perlakuan dapat dilihat pada table 2 .

Tabel 2. Nilai rata-rata kadar air ikan lele asap dari kombinasi perlakuan konsentrasi dan Suhu pemasakan

\begin{tabular}{ccccc}
\hline & $\mathrm{S} 1$ & $\mathrm{~S} 2$ & $\mathrm{~S} 3$ & $\begin{array}{c}\text { Rata- } \\
\text { rata }\end{array}$ \\
$\mathrm{K} 1$ & $62.07^{\mathrm{a}}$ & $59.70^{\mathrm{b}}$ & $57.52^{\mathrm{d}}$ & 59.76 \\
$\mathrm{~K} 2$ & $58.56^{\mathrm{c}}$ & $56.33^{\mathrm{f}}$ & $54.21^{\mathrm{h}}$ & 56.37 \\
$\mathrm{~K} 3$ & $56.58^{\mathrm{e}}$ & $54.84^{\mathrm{g}}$ & $51.21^{\mathrm{i}}$ & 54.21 \\
$\begin{array}{c}\text { Rata- } \\
\text { rata }\end{array}$ & 59.07 & 56.96 & 54.31 & 56.78 \\
\hline
\end{tabular}

Keterangan: Hasil analisis kadar air menunjukan bahwa berbeda nyata.

Berdasarkan hasil Analisis Sidik Ragam yang telah dilakukan menunjukkan bahwa perlakuan konsentrasi asap cair dan suhu pemasakan serta kombinasi kedua perlakuan berpengaruh sangat nyata $(\mathrm{P}<0,01)$ terhadap kadar air ikan lele asap yang dihasilkan. Tabel 2 menunjukkan bahwa kadar air ikan lele asap yang dihasilkan berkisar antara 51.21\% hingga $62.07 \%$. Nilai kadar air terendah adalah 51,21\% terdapat pada perlakuan konsentrasi 3\% dan suhu pemasakan $100^{\circ} \mathrm{C}\left(\mathrm{K}_{3} \mathrm{~S}_{3}\right)$. Nilai kadar air tertinggi adalah $62,07 \%$ terdapat pada perlakuan konsentrasi $1 \%$ dan suhu pemasakan $60^{\circ} \mathrm{C}\left(\mathrm{K}_{1} \mathrm{~S}_{1}\right)$. Nilai rata-rata kadar air kombinasi perlakuan konsentrasi asap cair dan suhu pemasakan adalah 56,78\%. Karena semakin besar konsentrasi asap cair maka akan menyebabkan semakin kecil nilai kandungan kadar air yang dihasilkan.

\section{Kadar Abu}

Kadar abu merupakan parameter nilai gizi suatu bahan produk yang dihasilkan oleh komponen zat organic yang terdapat di dalam ikan. Menurut Winarno (1995), sebagian besar bahan makanan, yaitu sekitar 96\% terdiri dari bahan organik dan air. Sisanya terdiri dari unsur-unsur mineral. Menurut Sudarmaji et al. (2003). Adapun rata-rata nilai kadar abuproduk ikan lele asap dari berbagai kombinasi perlakuan dapat dilihat pada Tabel 3 .

Tabel 3. Nilai rata-rata kadar abu produk ikan lele asap dari kombinasi perlakuan konsentrasi dan Suhu pemasakan

\begin{tabular}{ccccc}
\hline & $\mathrm{S} 1$ & $\mathrm{~S} 2$ & $\mathrm{~S} 3$ & $\begin{array}{c}\text { Rata- } \\
\text { rata }\end{array}$ \\
$\mathrm{K} 1$ & $1.64^{\mathrm{e}}$ & $1.91^{\mathrm{d}}$ & $2.21^{\mathrm{c}}$ & 1.92 \\
$\mathrm{~K} 2$ & $1.94^{\mathrm{d}}$ & $2.20^{\mathrm{c}}$ & $2.41^{\mathrm{b}}$ & 2.18 \\
$\mathrm{~K} 3$ & $2.18^{\mathrm{c}}$ & $2.36^{\mathrm{b}}$ & $2.70^{\mathrm{a}}$ & 2.41 \\
$\begin{array}{c}\text { Rata- } \\
\text { rata }\end{array}$ & 1.92 & 2.16 & 2.44 & 2.17 \\
\hline
\end{tabular}

Keterangan: Huruf yang sama dibelakang angka pada baris dan kolom yang sama menunjukkan nilai yang tidak berbeda nyata $(\mathrm{P}>0.05)$.

Berdasarkan Hasil Analisis Sidik Ragam yang telah dilukan menunjukkan bahwa perlakuan konsentrasi asap cair dan suhu pemasakan serta kombinasi kedua perlakuan berpengaruh sangat nyata $(\mathrm{P}<0,01)$ terhadap kadar abu ikan lele asap yang dihasilkan. Tabel 3 menunjukkan bahwa kadar abu ikan lele asap yang dihasilkan berkisar antara 1,64\% hingga 2,70\%. Nilai kadar abu terendah adalah $1,64 \%$ terdapat pada perlakuan konsentrasi $1 \%$ dan suhu pemasakan $60^{\circ} \mathrm{C}$ $\left(\mathrm{K}_{1} \mathrm{~S}_{1}\right)$. Nilai kadar abu tertinggi adalah $2,70 \%$ terdapat pada perlakuan konsentrasi 3\% dan suhu pemasakan $100^{\circ} \mathrm{C}\left(\mathrm{K}_{3} \mathrm{~S}_{3}\right)$. Nilai rata-rata kadar abu kombinasi perlakuan konsentrasi asap cair dan suhu pemasakan adalah $2,17 \%$. Semakin tinggi konsentrasi dan suhu pemasakan makan akan semakin tinggi nilai kadar abu yang dihasilkan suhu pemasakan, hal ini disebabkan karena semakin banyaknya air yang teruapkan dari bahan yang dikeringkan.

\section{Kadar Protein}

Hadiwiyoto (1993) mengatakan bahwa protein ikan merupakan komponen terbesar dalam jumlahnya setelah kadar air dan menjadi salah satu bagian yang sangat berguna bagi tubuh manusia. Adapun rata-rata 
nilai kadar protein produk ikan lele asap dari berbagai kombinasi perlakuan terdapat pada Tabel 4.

Tabel 4. Nilai rata-rata kadar protein produk ikan lele asap dari kombinasi perlakuan konsentrasi dan suhu pemasakan

\begin{tabular}{ccccc} 
& S1 & S2 & S3 & Rerata \\
K1 & $5.87^{\mathrm{g}}$ & $9.71^{\mathrm{f}}$ & $12.34^{\mathrm{e}}$ & 9.31 \\
$\mathrm{~K} 2$ & $9.80^{\mathrm{f}}$ & $13.25^{\mathrm{e}}$ & $17.65^{\mathrm{c}}$ & 13.57 \\
$\mathrm{~K} 3$ & $13.42^{\mathrm{d}}$ & $17.91^{\mathrm{b}}$ & $21.22^{\mathrm{a}}$ & 17.52 \\
Rerata & 9.70 & 13.62 & 17.07 & 13.46 \\
\hline
\end{tabular}

Keterangan: Huruf yang sama dibelakang angka pada baris dan kolom yang sama menunjukkan nilai yang tidak berbeda nyata $(\mathrm{P}>0.05)$.

Berdasarkan Hasil Analisis Sidik Ragam yang telah dilakukan menunjukkan bahwa perlakuan konsentrasi asap cair dan suhu pemasakan serta kombinasi kedua perlakuan berpengaruh sangat nyata $(\mathrm{P}<0,01)$ terhadap kadar protein ikan lele asap yang dihasilkan. Tabel 4 menunjukkan bahwa kadar protein ikan lele asap yang dihasilkan berkisar antara 5,87\% hingga $21,22 \%$. Nilai kadar protein terendah adalah 5,87\% terdapat pada perlakuan konsentrasi $1 \%$ dan suhu pemasakan $60^{\circ} \mathrm{C}\left(\mathrm{K}_{1} \mathrm{~S}_{1}\right)$. Nilai kadar protein tertinggi adalah $21.22 \%$ terdapat pada perlakuan konsentrasi $3 \%$ dan suhu pemasakan $100^{\circ} \mathrm{C}\left(\mathrm{K}_{3} \mathrm{~S}_{3}\right)$. Nilai rata-rata kadar protein kombinasi perlakuan konsentrasi asap cair dan suhu pemasakan adalah 13,46\%. Kenaikan dan penurunan kadar protein ini terjadi karena adanya aktivitas mikroba yang menguraikan protein (Soedjati, 2006). Hal ini membuktikan bahwa semakin tinggi konsentrasi asap cair batang bambu tabah dan suhu pemasakan, maka nilai kadar protein akan semakin meningkat.

\section{Kadar Lemak}

Lemak menjadi zat makanan yang dibutuhkan bagi manusia ini disebabkan karena berperan dalam proses metabolism tubuh. Winarno (1997) mengemukakan bahwa, penambahan lemak bertujuan untuk memberikan rasa yang gurih, kualiatas yang renyah, memberikan kandungan kolori yang tinggi dan memberikan sifat empuk pada produk. Adapun ratarata nilai kadar lemak pada produk ikan lele asap dari berbagai kombinasi perlakuan dapat dilihat pada Tabel 5.
Tabel 5. Nilai rata-rata kadar protein ikan lele asap dari kombinasi perlakuan konsentrasi dan suhu pemasakan

\begin{tabular}{ccccc} 
& S1 & S2 & S3 & Rerata \\
K1 & 5.50 & 5.70 & 5.40 & 5.53 \\
K2 & 5.45 & 5.60 & 5.80 & 5.62 \\
K3 & 5.30 & 5.45 & 5.75 & 5.50 \\
Rerata & 5.42 & 5.58 & 5.65 & 5.55 \\
\hline
\end{tabular}

Berdasarkan Hasil Analisis Sidik Ragam yang telah dilakukan menunjukan bahwa perlakuan konsentrasi asap cair dan suhu pemasakan berpengaruh nyata $(\mathrm{P}<0,01)$ terhadap kadar lemak ikan lele asap. Tetapi kombinasi kedua perlakuan tidak berpengaruh (tidak berinteraksi). Tabel 5. Menunjukan bahwa nilai kadar lemak produk ikan lele asap berkisar antara 5,30\% hingga 5,80\%. Nilai kadar lemak terendah adalah $5,30 \%$ terdapat pada perlakuan konsentrasi $1 \%$ dan suhu pemasakan $60^{\circ} \mathrm{C}\left(\mathrm{K}_{3} \mathrm{~S}_{1}\right)$. Nilai kadar lemak tertinggi adalah $5,80 \%$ terdapat pada perlakuan konsentrasi $2 \%$ dan suhu pemasakan $80^{\circ} \mathrm{C}\left(\mathrm{K}_{2} \mathrm{~S}_{3}\right)$. Nilai rata-rata kadar lemak kombinasi perlakuan konsentrasi asap cair dan suhu pemasakan adalah $5,55 \%$. Semakin tinggi konsentrasi dan suhu pemasakan maka Kadar lemak ikan lele asap akan menurun. Hal ini disebabkan karena terjadinya oksidasi lemak yang mengakibatkan penurunan kandungan nilai kadar lemak. Winarno (1997), Molekul - moleku lemak yang mengandung asam lemak tidak jenuh mengalami oksidasi secara otooksidasi.

\section{Uji Sensorik}

Uji organoleptik merupakan suatu uji penginderaan yang biasa dilakukan terhadap bahan pangan. Dasar dari pengujian ini adalah kesensitifan alat indera dalam melihat, mencium, merasakan maupun meraba suatu bahan pangan, tujuannya adalah untuk mengetahui tingkat kesukaan konsumen terhadap produk yang diteliti atau diolah. Metode ini merupakan cara yang digunakan untuk mengukur, menganalisa dan menginterpretasikan karakter dari suatu bahan pangan. Uji organoleptik dilakukan oleh 15 orang panelis. Produk ikan lele asap yang sudah tersedia diatas meja langsung diuji mulai dari kenampakan, bau, rasa, dan tekstur. Pengujian organoleptik dapat dilihat pada Tabel 6.

Tabel 6. Nilai rata-rata uji sensori kenampakan, bau, rasa, dan tekstur ikan lele asap

\begin{tabular}{|c|c|c|c|c|}
\hline \multicolumn{5}{|c|}{ Nilai Rata-rata Uji Skoring (S) ikan lele asap } \\
\hline Sampel & $\begin{array}{l}\text { Warna } \\
\text { (S) }\end{array}$ & $\begin{array}{c}\text { Aroma } \\
(\mathrm{S})\end{array}$ & $\begin{array}{c}\text { Rasa } \\
\text { (S) }\end{array}$ & $\begin{array}{l}\text { Tekstur } \\
\text { (H) }\end{array}$ \\
\hline
\end{tabular}




\begin{tabular}{lllll}
\hline $\mathrm{K} 1 \mathrm{~S} 1$ & $2.33^{\mathrm{f}}$ & $2.33^{\mathrm{d}}$ & $2.87^{\mathrm{d}}$ & 2.80 \\
$\mathrm{~K} 1 \mathrm{~S} 2$ & $3.53^{\mathrm{d}}$ & $2.60^{\mathrm{d}}$ & $3.47^{\mathrm{c}}$ & 3.60 \\
$\mathrm{~K} 1 \mathrm{~S} 3$ & $2.87^{\mathrm{e}}$ & $3.60^{\mathrm{c}}$ & $3.60^{\mathrm{c}}$ & 3.40 \\
$\mathrm{~K} 2 \mathrm{~S} 1$ & $3.67^{\mathrm{c}}$ & $3.40^{\mathrm{c}}$ & $3.93^{\mathrm{b}}$ & 4.13 \\
$\mathrm{~K} 2 \mathrm{~S} 2$ & $4.00^{\mathrm{b}}$ & $4.33^{\mathrm{b}}$ & $4.53^{\mathrm{a}}$ & 3.80 \\
$\mathrm{~K} 2 \mathrm{~S} 3$ & $3.93^{\mathrm{b}}$ & $4.80^{\mathrm{a}}$ & $4.27^{\mathrm{a}}$ & 4.20 \\
$\mathrm{~K} 3 \mathrm{~S} 1$ & $4.33^{\mathrm{a}}$ & $4.47^{\mathrm{a}}$ & $4.73^{\mathrm{a}}$ & 4.20 \\
$\mathrm{~K} 3 \mathrm{~S} 2$ & $4.67^{\mathrm{a}}$ & $4.40^{\mathrm{b}}$ & $4.40^{\mathrm{a}}$ & 4.07 \\
$\mathrm{~K} 3 \mathrm{~S} 3$ & $4.47^{\mathrm{a}}$ & $4.27^{\mathrm{b}}$ & $4.60^{\mathrm{a}}$ & 4.53 \\
\hline
\end{tabular}

Keterangan: Huruf yang sama dibelakang angka pada baris dan kolom yang sama menunjukkan nilai yang tidak berbeda nyata $(\mathrm{P}>0.05)$.

\section{Warna}

Hasil Sidik Ragam menunjukkan bahwa konsentrasi dan suhu pemasakan berpengaruh sangat nyata $(\mathrm{p}<0,01)$ dan kombinasi keduanya berpengaruh nyata $(\mathrm{P}<0,05)$ terhadap nilai rata-rata uji skoring warna ikan lele asap. Tabel 6 menunjukkan bahwa nilai ratarata tertinggi uji skoring warna diperoleh pada perlakuan konsentrasi asap cair batang bambu tabah $3 \%\left(\mathrm{~K}_{3}\right)$ dan suhu pemasakan $100^{\circ} \mathrm{C}\left(\mathrm{S}_{2}\right)$ yaitu sebesar 4,67 (Coklat emas) . Sedangkan nilai rata-rata terendah uji skoring warna diperoleh pada perlakuan konsentrasi asap cair $1 \%\left(\mathrm{~K}_{1}\right)$ dan suhu pemasakan $60^{\circ} \mathrm{C}\left(\mathrm{S}_{1}\right)$ yaitu sebesar 2,33 (coklat). Semakin tinggi kadar karbonil semakin tinggi potensi pencoklatannya (Putra, 2010).

\section{Aroma}

Hasil Sidik Ragam menunjukkan bahwa konsentrasi dan suhu pemasakan berpengaruh sangat nyata $(\mathrm{p}<0,01)$ dan kombinasi keduanya berpengaruh nyata $(\mathrm{P}<0,05)$ terhadap nilai rata-rata uji skoring aroma ikan lele asap. Tabel 6 menunjukkan bahwa nilai ratarata tertinggi uji skoring aroma diperoleh pada perlakuan konsentrasi asap cair batang bambu tabah $2 \%\left(\mathrm{~K}_{2}\right)$ dan suhu pemasakan $80^{\circ} \mathrm{C}\left(\mathrm{S}_{3}\right)$ yaitu sebesar 4,80 (Harum asap cukup). Sedangkan nilai rata-rata terendah uji skoring aroma diperoleh pada perlakuan konsentrasi asap cair $1 \%\left(\mathrm{~K}_{1}\right)$ dan suhu pemasakan $60^{\circ} \mathrm{C}\left(\mathrm{S}_{1}\right)$ yaitu sebesar 2,33 (Keharuman hampir netral). Semakin tinggi konsentrasi asap cair bambu tabah dan suhu pemasakan yang diberikan, maka aroma atau bau asap cair akan semakin meningkat. (Afrianto dan Liviawaty, 1989).

\section{Rasa}

Hasil Sidik Ragam menunjukkan bahwa konsentrasi dan suhu pemasakan berpengaruh sangat nyata $(p<0,01)$ dan kombinasi keduanya berpengaruh nyata $(\mathrm{P}<0,05)$ terhadap nilai rata-rata uji skoring rasa ikan lele asap. Tabel 6 menunjukkan bahwa nilai rata-rata tertinggi uji skoring rasa diperoleh pada perlakuan konsentrasi asap cair bamboo tabah $2 \%\left(\mathrm{~K}_{2}\right)$ dan suhu pemasakan $80^{\circ} \mathrm{C}\left(\mathrm{S}_{1}\right)$ yaitu sebesar 4,93(Gurih). Sedangkan nilai rata-rata terendah uji skoring rasa diperoleh pada perlakuan konsentrasi asap cair 1\%
$\left(\mathrm{K}_{1}\right)$ dan suhu pemasakan $60^{\circ} \mathrm{C}\left(\mathrm{S}_{1)}\right.$ yaitu sebesar 2,87 (Tidak enak). Yulstiani (2008) mengemukakan bahwa, spesifik cita rasa produk hasil pengasapan dihasilkan dari senyawa fenolik yang terserap didalam produk. Menurut penelitian yang dilakukan oleh Adel Tuyu et al.(2014) menyatakan bahwa menurutnya kadar air mempengaruhi tingkat kesukaan panelis pada ikan selar asin.

\section{Tekstur}

Hasil sidik ragam menunjukkan bahwa konsentrasi dan suhu pemasakan pada ikan lele asap berpengaruh sangat nyata $(\mathrm{P}<0,01)$, namun faktor konsentrasi dan suhu pemasakan tidak berinteraksi $(\mathrm{P}>0,05)$ terhadap nilai rata-rata uji skoring ikan lele asap. Tabel 6 menunjukkan bahwa nilai rata-rata tertinggi uji skoring tekstur diperoleh pada perlakuan dengan konsentrasi asap cair batang bambu tabah 3\% dan suhu pemasakan $100^{\circ} \mathrm{C}$ yaitu sebesar 4,53 (Padat). Sedangkan nilai rata-rata terendah uji skoring tekstur diperoleh pada perlakuan konsentrasi asap cair $1 \%$ dan suhu pemasakan $60^{\circ} \mathrm{C}$ yaitu sebesar 2,80 (lembek).

\section{KESIMPULAN DAN SARAN}

\section{Kesimpulan}

Berdasarkan penelitian ini dapat disimpulkan bahwa konsentrasi asap cair bambu tabah dan suhu pemasakan berpengaruh sangat nyata $(\mathrm{P}<0,01)$ terhadap nilai kadar air, $\mathrm{pH}$, kadar abu, kadar protein kadar lemak, organoleprtik kenampakan, bau, rasa dan tekstur. Interaksi antara konsentrasi asap cair bambu tabah dan suhu pemasakan tidak berinteraksi terhadap kadar lemak dan testur ikan lele asap. Kombinasi perlakuan terbaik yaitu pada pada suhu pemasakan $100^{\circ} \mathrm{C}$ dengan konsentrasi $3 \%$ selama 4 jam pemasakn dihasilkan nilai $\mathrm{pH} 5,61$, Kadar air $56.78 \%$, kadar abu $2.17 \%$, Kadar protein $13.46 \%$, Kadar lemak 5.55\%, uji hedonic warna 4,67(Coklat emas), aroma 4,80(Harum asap cukup), rasa 4,93(Enak), tekstur 4,53(padat).

\section{Saran}


Berdasarkan penelitian yang telah dilaksanakan, disarankan untuk menambah parameter penelitian mengenai nilai TPC (Total Plate Count) dan uji lanjut mengenai masa simpan ikan lele asap.

\section{DAFTAR PUSTAKA}

Afrianto, I. E., \& Liviawaty, I. E. (1989). Pengawetan dan pengolahan ikan. Kanisius.

Budijanto, S., Hasbullah, R., Prabawati, S., \& Zuraida, I. (2019). Identifikasi dan uji keamanan asap cair tempurung kelapa untuk produk pangan. Jurnal Penelitian Pascapanen Pertanian, 5(1), 32-40.

Darmadji, P. (1996). Aktivitas antibakteri asap cair yang diproduksi dari bermacam-macam limbah pertanian. Agritech, 16(1996).

DeMan, J. M. (1997). Kimia Makanan (Penerjemah: K. Patmawinata). Bandung: Penerbit Institut Teknologi Bandung.

Hadiwiyoto, S. (1993). Teknologi pengolahan hasil perikanan. Liberty.

Horwitz, W., Chichilo, P., \& Reynolds, H. (1970). Official methods of analysis of the Association of Official Analytical Chemists. Official methods of analysis of the Association of Official Analytical Chemists.

Kencana, P. K. D., Widia, W., \& Antara, N. S. (2012). Praktek Baik Budi Daya Bambu Rebuffing Bambu Tabah (Gigantochloa nigrociliata BUSE-KURZ). Balai Penelitian. Denpasar.

Pszcola 1995 Tour HghLightsProdlcton:nd r.lses Of SmokeAase FaYoE Food T€chnology

Putra, D. (2010). Asap Cair Pengawet Makanan. Asap-cairpengawet-makanan. wordpress. com. Diakses 04 Oktober 2016.

Sedjati, S. (2006). Pengaruh konsentrasi khitosan terhadap mutu ikan teri (Stolephorus heterolobus) asin kering selama penyimpanan suhu kamar (Doctoral dissertation, program Pascasarjana Universitas Diponegoro).

Soekarto, S. T. (1990). Dasar-dasar pengawasan dan standarisasi mutu pangan. Bogor: PAU Pangan dan Gizi, IPB.

Sudarmadji, S., \& Haryono, B. Suhardi. 1997. Prosedur analisa untuk bahan makanan dan pertanian (edisi keempat). Liberty. Yogyakarta.

Wibowo, S. 1996. Industri Pengasapan Ikan. Penebar Swadaya, Jakarta.

Winarno, F Wibowo, S. 1996. Industri Pengasapan Ikan. Penebar Swadaya, Jakarta. G. 1995. Kimia Pangan dan Gizi. Gramedia Pustaka Utama. Jakarta.

Citra, F., Yuliati, K., \& Baehaki, A. (2015). Analisis Mutu Ikan Lele (Clarias batrachus) Asap
Produksi Rakyat di Jalan Lintas Musi II Desa Keramasan, Kertapati, Palembang. Jurnal FishtecH, 4(1), 9-15.

Yazid, E., \& Nursanti, L. (2006). Penuntun Praktikum Biokimia untuk Mahasiswa Analis. Yogyakarta: Penerbit Andi. Hlm, 66-68. 